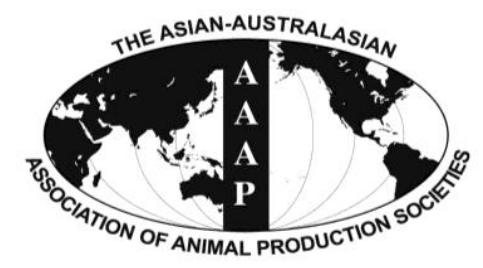

Asian-Aust. J. Anim. Sci.

Vol. 26, No. 3 : 378-385 March 2013

http://dx.doi.org/10.5713/ajas.2012.12180

www.ajas.info

pISSN 1011-2367 elSSN 1976-5517

\title{
The Effect of Variety and Growing Conditions on the Chemical Composition and Nutritive Value of Wheat for Broilers
}

\author{
M. E. E. Ball ${ }^{1,2, *}$, B. Owens ${ }^{2}$ and K. J. McCracken ${ }^{2}$ \\ ${ }^{1}$ Agri-Food and Biosciences Institute, Newforge Lane, Belfast, BT9 5PX, Northern Ireland, UK \\ ${ }^{2}$ The Queen's University of Belfast, Newforge Lane, Belfast BT9 5PX, Northern Ireland, UK
}

\begin{abstract}
The aim of this study was to examine the effect of variety and growing conditions of wheat on broiler performance and nutrient digestibility. One hundred and sixty-four wheat samples, collected from a wide range of different sources, locations, varieties and years, were analyzed for a range of chemical and physical parameters. Chemical and physical parameters measured included specific weight, thousand grain weight (TG), in vitro viscosity, gross energy, N, NDF, starch, total and soluble non-starch polysaccharides (NSP), lysine, threonine, amylose, hardness, rate of starch digestion and protein profiles. Ninety-four of the wheat samples were selected for inclusion in four bird trials. Birds were housed in individual wire metabolizm cages from 7 to $28 \mathrm{~d}$ and offered water and feed ad libitum. Dry matter intake (DMI), live weight gain (LWG) and gain:feed were determined weekly. A balance collection was carried out from 14 to $21 \mathrm{~d}$ for determination of apparent metabolizable energy (AME), ME:gain, DM retention, oil and NDF digestibility. At $28 \mathrm{~d}$ the birds were sacrificed, the contents of the jejunum removed for determination of in vivo viscosity and the contents of the ileum removed for determination of ileal DM, starch and protein digestibility. The wheat samples used in the study had wide-ranging chemical and physical parameters, leading to bird DMI, LWG, gain:feed, ME:GE, AME content and ileal starch and protein digestibility being significantly $(\mathrm{p}<0.05)$ affected by wheat sample. A high level of $\mathrm{N}$ fertilizer application to the English and NI wheat samples tended to benefit bird performance, with increases of up to 3.4, 7.2 and 3.8\% in DMI, LWG and gain:feed, respectively. Fungicide application also appeared to have a positive effect on bird performance, with fungicide treated $(+\mathrm{F})$ wheat increasing bird DMI, LWG and gain:feed by 6.6, 9.3 and $2.7 \%$, over the non-fungicide treated $(-F)$ wheats. An increase ( $\mathrm{p}<0.1)$ of $9.3 \%$ in gain:feed was also observed at the low seed rate of 40 compared to $640 \mathrm{seeds} / \mathrm{m}^{2}$. It was concluded that the type of wheat sample and environmental growing conditions significantly affects bird performance when fed wheat-based diets. (Key Words: Wheat, Broilers, Variety, Chemical Composition)
\end{abstract}

\section{INTRODUCTION}

Wheat is the major ingredient in diets for broilers across Europe and can contribute up to $700 \mathrm{~g} / \mathrm{kg}$ of the diet. However, it is well recognized that different batches of wheat can result in variable broiler performance which is attributed to variability in wheat chemical composition and nutritive value. McCracken et al. (2002) examined the effect of wheat variety and location on production $(n=12)$ on the chemical composition and nutritive value of wheat for broilers. These workers reported a wide range in specific weight ( 63.2 to $77.1 \mathrm{~kg} / \mathrm{hl}$ ), in vitro viscosity (5.2 to 17.5 cps), crude protein (CP, 116 to $147 \mathrm{~g} / \mathrm{kg} \mathrm{DM}$ ) resulting in a range in apparent metabolizable energy (AME, 13.2 to 14.2

\footnotetext{
* Corresponding Author: M. E. E. Ball.

E-mail: elizabeth.ball@afbini.gov.uk

Submitted Apr. 5, 2012; Accepted May 10, 2012; Revised Jun. 13, 2012
}

$\mathrm{MJ} / \mathrm{kg} \mathrm{DM})$.

It has been well established that the conditions of growth can have an influence on the chemical composition and nutritive value of wheat for broilers. Metayer et al. (1993) showed that wheat grown in the North East of France had a higher nutritional value than wheat grown in Brittany and the South East of France. Additionally, the year of production or growing conditions can have a dramatic effect on chemical composition (George and McCracken, 2003). Furthermore, the level of CP can be correlated with the level of $\mathrm{N}$ fertilizer (Uhlen et al., 2004). However, to date there is no real understanding in the literature regarding why nutritive value should vary and no single chemical or physical parameter can be identified as the main contributor of variation (Ball et al., 2012).

Choct and Annison (1990, 1992) and several other workers have reported that non starch polysaccharides (NSP) 
present in cereal grains can reduce nutrient digestibility and bird performance. The main NSP in wheat is arbinoxylan (ranging from 57 to $80 \mathrm{~g} / \mathrm{kg} \mathrm{DM}$ ) which are thought to tangle up within the gastrointestinal tract and hinder digestion (Gutierrez-Alamo et al., 2008).

While there has been considerable research conducted on the factors affecting wheat nutritive value for broilers, the majority of the work has been conducted on smaller datasets (e.g. McCracken et al. (2002), $n=12$; Pirgozliev et al. (2003), $n=23$ ) and more work is needed in this area using larger datasets. In addition, the effect of seed rate as well as fungicide use on wheat nutritive value has not yet been investigated. Therefore, the aim of this study was to establish a large dataset of wheat of different varieties and grown under different conditions in order to investigate the effect on the variability of nutritive value when included in broiler diets.

\section{MATERIALS AND METHODS}

\section{Animal ethics}

This study was conducted according to the Animals (Scientific Procedures) Act 1986 and was approved by the Newforge Ethical Committee.

\section{Sample collection}

The 164 wheat samples used in this study were gathered over a wide range of different locations, varieties and years. Sixty-two of the wheat samples were taken from Miller et al. (2001). Of these, 30 were from the 1998 harvest from Northern Irish plant testing stations at Crossnacreevy, Downpatrick and Limavady (ten varieties: Cantata, Ritmo, Riband, Chaucer, Reaper, Brigadier, Madrigal, Hussar, Harrier and Equinox from each site). The other 32 consisted of eight 1999 Northern Ireland (NI) varieties (Aardvark, Charger, Hereward, Reaper, Equinox, Napier, Rialto, Savannah and Consort) from two sites (Downpatrick and Limavady) and 16 wheats from Great Britain (GB), of four different varieties (Buster, Consort, Riband and Haven) at four levels of specific weight. In addition to these, ten samples: Claire, Consort, Malacca, Tanker, Napier, Savannah, Aarvark, Rialto, Riband and Soissons were collected from each of the 2003 and 2004 harvests at Crossnacreevy, NI. Another 20 samples: Claire, Consort, Malacca, Tanker, Soissons, Riband, Napier, Goodwood, Savannah and Vector, at high and low nitrogen levels (180 $\mathrm{kg} \mathrm{N} / \mathrm{ha}$ and $260 \mathrm{~kg} \mathrm{~N} / \mathrm{ha}$ ), were collected from the 2005 harvest at Crossnacreevy. Another 30 samples were taken from HGCA Project No. 2979 entitled "GREEN Grain" being undertaken by ADAS, England. These samples contained wheat with and without nitrogen and fungicide application and at different seed rates (640, 160 and 40 seeds $/ \mathrm{m}^{2}$, respectively) over three different locations:
Terrington, High Mowthorpe and Rosemaund. Ten samples were obtained from shipments from GB containing commercial wheat samples for Moy Park Limited (Dungannon, Northern Ireland) and the remaining 22 samples were sourced from Canada (Pacific Agri-Food Research Centre, Agassiz, B.C.).

Of the above wheat samples 94 were selected for inclusion in four animal trials as described by Ball et al. (2012).

Analysis of wheat samples, diets, excreta and ileal digesta were carried out according to the procedures outlined by Ball et al. (2012).

\section{Statistical analysis}

The range, minimum, mean, maximum and standard deviation for wheat chemical analysis, bird performance and nutrient digestibility were calculated. The effect of year, variety, location of production, $\mathrm{N}$ and fungicide application and seed rate were tested for using analysis of variance (Genstat Release 9.2). Individual bird data was taken as the experimental unit with initial weight used as a co-variate for growth and nutrient digestibility parameters.

\section{RESULTS}

\section{Chemical and physical analysis of wheat samples}

The chemical and physical analyses of the wheat samples are summarized in Table 1 and 2. Specific weight (SW) ranged from $59 \mathrm{~kg} / \mathrm{hl}$ (Equinox, Crossnacreevy, 1998) to $78 \mathrm{~kg} / \mathrm{hl}$ (Buster $78 \mathrm{~kg} / \mathrm{hl} \mathrm{SW}, 1998 / 99)$ ). Wheat from the 2004 harvest had the highest mean SW values $(73.0 \mathrm{~kg} / \mathrm{hl})$ of all NI wheat and the 1998 harvest the lowest $(68.3 \mathrm{~kg} / \mathrm{hl})$. The high $\mathrm{N}$ wheat from the 2005 harvest had similar mean values $(72.2 \mathrm{~kg} / \mathrm{hl})$ when compared with low nitrogen wheats $(70.7 \mathrm{~kg} / \mathrm{hl})$. The high nitrogen and fungicide wheat samples from HGCA Project 2979 had slightly higher mean SW values (72.8 and $74.3 \mathrm{~kg} / \mathrm{hl}$, respectively) than those without $(70.8$ and $68.0 \mathrm{~kg} / \mathrm{hl})$. Wheat from Rosemaund and Plough had similar mean SW $(72.5 \mathrm{~kg} / \mathrm{hl})$ to those from Terrington $(71.4 \mathrm{~kg} / \mathrm{hl})$ or High Mowthorpe $(71.1 \mathrm{~kg} / \mathrm{hl})$. SW was similar for wheat samples with seed rate of 160 $(72.9 \mathrm{~kg} / \mathrm{hl}), 40(71.4 \mathrm{~kg} / \mathrm{hl})$ and $640(71.3 \mathrm{~kg} / \mathrm{hl})$. Of all the sources of wheat samples, the commercial wheat from GB had the greatest mean $\mathrm{SW}$ value $(73.3 \mathrm{~kg} / \mathrm{hl})$ and $1998 \mathrm{NI}$ wheat the lowest $(68.3 \mathrm{~kg} / \mathrm{hl})$.

Thousand grain weight (TG) ranged from $21.7 \mathrm{~g}$ (Acbarrie, Manitoba, plot 26, Canadian wheat) to $60.8 \mathrm{~g}$ (Riband, 2004). For NI, mean TG was highest for the 2004 harvest $(57.5 \mathrm{~g})$ and lowest for the 2005 harvest (42.3 g). The mean TG of the high and low N wheat from the 2005 harvest were identical $(42.3 \mathrm{~g})$. The high $\mathrm{N}$ and fungicide wheat samples from HGCA Project 2979 had greater mean TG values (43.6 and $43.4 \mathrm{~g}$ respectively) than those without 
Table 1. Chemical and physical analysis of wheats as grouped by year of production, location and conditions of growth

\begin{tabular}{|c|c|c|c|c|c|c|c|c|c|c|c|}
\hline & $\begin{array}{c}\text { SW } \\
(\mathrm{g} / \mathrm{hl})\end{array}$ & $\begin{array}{l}\text { TG } \\
(\mathrm{g})\end{array}$ & $\begin{array}{l}\text { IVV } \\
(\mathrm{cp})\end{array}$ & $\begin{array}{c}\mathrm{N} \\
(\mathrm{g} / \mathrm{kg} \mathrm{DM})\end{array}$ & $\begin{array}{c}\mathrm{CP} \\
(\mathrm{g} / \mathrm{kg} \mathrm{DM})\end{array}$ & $\begin{array}{c}\text { NDF } \\
(\mathrm{g} / \mathrm{kg} \mathrm{DM})\end{array}$ & $\begin{array}{c}\text { Starch } \\
(\mathrm{g} / \mathrm{kg} \mathrm{DM})\end{array}$ & $\begin{array}{l}\text { Total NSP } \\
\text { (g/kg DM) }\end{array}$ & $\begin{array}{c}\text { Sol NSP } \\
\text { (g/kg DM) }\end{array}$ & $\begin{array}{c}\text { GE } \\
(\mathrm{MJ} / \mathrm{kg} \mathrm{DM})\end{array}$ & $\begin{array}{l}\text { Amylose } \\
\text { (g/kg DM) }\end{array}$ \\
\hline 1998 & 68.3 & 42.4 & 17.2 & 20.3 & 118.4 & 132.7 & 641 & 104.7 & 24.1 & 18.35 & 157.9 \\
\hline $1998 / 99$ & 69.8 & 47.0 & 14.5 & 20.1 & 117.0 & 132.2 & 673 & 117.0 & 26.7 & 18.40 & 162.1 \\
\hline 2003 & 71.7 & 43.7 & 15.7 & 18.4 & 107.0 & 144.2 & 622 & 109.9 & 19.56 & 18.30 & 152.0 \\
\hline 2004 & 73.0 & 57.5 & 15.0 & 18.7 & 109.0 & 147.0 & 603 & 104.2 & 25.1 & 18.39 & 173.3 \\
\hline \multicolumn{12}{|l|}{2005} \\
\hline All & 71.4 & 42.3 & 9.9 & 17.2 & 100.0 & 142.3 & 640 & 101.3 & 21.1 & 18.30 & 154.1 \\
\hline High $\mathrm{N}$ & 72.2 & 42.3 & 10.3 & 18.2 & 106.0 & 147.0 & 634 & 107.0 & 20.7 & 18.35 & 142.0 \\
\hline Low N & 70.7 & 42.3 & 9.4 & 16.1 & 94.0 & 137.0 & 645 & 96.0 & 21.5 & 18.26 & 166.0 \\
\hline \multicolumn{12}{|l|}{ English } \\
\hline All & 71.6 & 42.6 & 9.0 & 18.4 & 107.4 & 145.1 & 636 & 104.2 & 22.3 & 18.36 & 158.0 \\
\hline$+\mathrm{N}$ & 72.8 & 43.6 & 7.5 & 19.1 & 111.5 & 143.1 & 639 & 100.5 & 23.4 & 18.40 & 157.5 \\
\hline$-\mathrm{N}$ & 70.8 & 42.6 & 6.9 & 13.9 & 80.8 & 136.8 & 665 & 97.6 & 20.6 & 18.18 & 168.0 \\
\hline$+\mathrm{F}$ & 74.3 & 43.4 & 8.6 & 19.9 & 116.3 & 134.5 & 623 & 103.2 & 20.4 & 18.33 & 149.1 \\
\hline$-F$ & 68.0 & 33.7 & 9.8 & 22.3 & 130.1 & 161.8 & 610 & 111.8 & 23.4 & 18.51 & 148.2 \\
\hline Terr & 71.4 & 41.4 & 5.2 & 16.6 & 96.7 & 137.7 & 646 & 96.0 & 21.2 & 18.24 & 168.0 \\
\hline $\mathrm{HM}$ & 71.1 & 40.8 & 8.5 & 18.5 & 108.1 & 143.9 & 636 & 105.0 & 22.0 & 18.33 & 151.7 \\
\hline Rose & 72.5 & 45.0 & 11.4 & 19.0 & 110.7 & 147.6 & 637 & 107.8 & 23.6 & 18.48 & 162.8 \\
\hline Plough & 72.5 & 48.2 & 13.8 & 20.3 & 118.2 & 159.7 & 612 & 109.1 & 23.4 & 18.47 & 155.5 \\
\hline $\mathrm{S} / \mathrm{R} 40$ & 71.4 & 50.3 & 12.1 & 21.0 & 122.2 & 157.8 & 616 & 117.4 & 23.3 & 18.52 & 155.4 \\
\hline $\mathrm{S} / \mathrm{R} 160$ & 72.9 & 45.9 & 14.6 & 20.4 & 119.0 & 151.2 & 612 & 117.6 & 24.8 & 18.49 & 157.4 \\
\hline $\mathrm{S} / \mathrm{R} 640$ & 71.3 & 43.9 & 14.6 & 18.7 & 109.0 & 155.5 & 626 & 106.5 & 23.5 & 18.43 & 159.0 \\
\hline GB & 73.3 & 42.2 & 14.1 & 19.9 & 116.3 & 139.3 & 614 & 101.9 & 22.1 & 18.33 & 167.7 \\
\hline Canadian & $*$ & 32.5 & 6.2 & 26.9 & 156.6 & 152.8 & 579 & 108.7 & 20.6 & 18.66 & 162.7 \\
\hline
\end{tabular}

$\mathrm{SW}=$ Specific weight, $\mathrm{TG}=$ Thousand grain weight, $\mathrm{IVV}=$ In vitro viscosity, $\mathrm{N}=$ Nitrogen, $\mathrm{CP}=$ Crude protein, $\mathrm{NDF}=\mathrm{Neutral}$ detergent fibre, $\mathrm{NSP}=$ Non starch polysaccharide, $\mathrm{GE}=$ Gross energy, $\mathrm{F}=$ Fungicide, Terr $=$ Terrington, $\mathrm{HM}=$ High Mowthrope, Rose $=$ Rosemaund, $\mathrm{S} / \mathrm{R}=\mathrm{Seed}$ rate .

(42.6 and $33.7 \mathrm{~g}$, respectively). Wheat samples from Plough had greater mean TG (48.2 g), than Rosemaund (45.0 g), Terrington (41.4 g) or High Mowthorpe (40.8 g). As expected, the lowest seed rate of 40 gave the highest mean TG (50.3 g) and the highest seed rate of 640 gave the lowest (43.9 g). The wheat samples obtained from the $2004 \mathrm{NI}$ harvest gave the highest mean TG $(57.5 \mathrm{~g})$ and the Canadian wheat samples the lowest (32.5 g).

In vitro viscosity (IVV) ranged from $3.2 \mathrm{cp}$ (Acbarrie, Manitoba, plot 26, Canadian wheat) to $44 \mathrm{cp}$ (Haven 71, 1998/99). Of the NI samples, wheat harvested in 1998 had the highest mean IVV (17.2 cp) and 2005 the lowest (9.9 $\mathrm{cp})$. The high nitrogen wheat from the 2005 harvest had similar mean IVV (10.3) than the low nitrogen (9.4 cp). The "with N" wheat samples from HGCA Project 2979 had similar mean IVV $(7.5 \mathrm{cp})$ than those without $(6.6 \mathrm{cp})$, while the "with fungicide" wheat samples had slightly lower mean IVV $(8.6 \mathrm{cp})$ than those without $(9.8 \mathrm{cp})$. Wheat samples from Plough had greater mean IVV $(13.8 \mathrm{cp})$, than Rosemaund (11.4 cp), High Mowthorpe (8.5 cp) or Terrington $(5.2 \mathrm{cp})$. The wheats with the higher seed rates of 640 and 160 had slightly greater mean IVV (14.6 cp) than those with the lower seed rate $(12.1 \mathrm{cp})$. Overall, wheat sourced from the 1998 NI harvest had the highest mean IVV (17.2 cp) and the Canadian wheats the lowest $(6.2 \mathrm{cp})$.
Nitrogen content $(\mathrm{N})$ ranged from $12.5 \mathrm{~g} / \mathrm{kg} \mathrm{DM}$ (Zebedee, -N, HGCA Project 2979) to $32.6 \mathrm{~g} / \mathrm{kg} \mathrm{DM}$ (BW252, AAFCWPG, plot 55, Canadian wheat). Of the NI samples, mean $\mathrm{N}$ was highest for wheat harvested in 1998 $(20.3 \mathrm{~g} / \mathrm{kg} \mathrm{DM})$ and lowest for that harvested in 2005 (17.2 $\mathrm{g} / \mathrm{kg} \mathrm{DM})$. As expected, the "high nitrogen" wheat from the 2005 harvest had greater mean N (18.2 g/kg DM) than the low (16.1 g/kg DM). Similarly, the "with N" wheat from HGCA Project 2979 had higher mean N (19.1 g/kg DM) than the "without" (13.9 g/kg DM), while the "with fungicide" wheat had lower mean N (19.9 g/ $\mathrm{kg} \mathrm{DM})$ than the "without" (22.3 g/kg DM). Wheat samples from Plough had slightly greater mean $\mathrm{N}(20.3 \mathrm{~g} / \mathrm{kg} \mathrm{DM})$, than Rosemaund (19.0 g/kg DM), High Mowthorpe $(18.5 \mathrm{~g} / \mathrm{kg}$ $\mathrm{DM})$ or Terrington $(16.6 \mathrm{~g} / \mathrm{kg} \mathrm{DM})$, and the higher the seed rate the lower the $\mathrm{N}$ content. Overall, wheat sourced from the 2005 NI harvest had the lowest N (17.2 g/ $\mathrm{kg} \mathrm{DM})$ and the Canadian wheat the highest $(26.9 \mathrm{~g} / \mathrm{kg} \mathrm{DM})$.

The NDF content of the wheat samples ranged from 101 $\mathrm{g} / \mathrm{kg} \mathrm{DM}$ (Consort 78, 1998/99) to $195 \mathrm{~g} / \mathrm{kg}$ DM (Sceptre, TL9801, plot 82, Canadian wheat). Of the wheat sourced from NI, the 1998/99 harvest had the lowest mean NDF $(132 \mathrm{~g} / \mathrm{kg} \mathrm{DM})$ and the 2004 harvest the highest $(147 \mathrm{~g} / \mathrm{kg}$ DM). From the wheat sourced from HGCA Project 2979, the "with N" wheat had similar mean NDF content (143 
Table 2. Range and standard deviation of chemical and physical parameters of wheat

\begin{tabular}{|c|c|c|c|c|}
\hline & Minimum & Mean & Maximum & Standard deviation \\
\hline Specific weight $(\mathrm{kg} / \mathrm{hl})$ & 60.0 & 71.3 & 78.0 & 3.99 \\
\hline Thousand grain weight $(\mathrm{g})$ & 28.7 & 45.6 & 60.8 & 7.85 \\
\hline In vitro viscosity (cp) & 4.3 & 12.4 & 44.0 & 6.87 \\
\hline Nitrogen (g/kg DM) & 12.5 & 18.8 & 24.0 & 2.57 \\
\hline Neutral detergent fibre (g/kg DM) & 101.3 & 139.6 & 178.6 & 13.13 \\
\hline Starch $(\mathrm{g} / \mathrm{kg} \mathrm{DM})$ & 567.0 & 644.2 & 719.0 & 31.72 \\
\hline Total non starch polysaccharide (g/kg DM) & 81.7 & 108.3 & 138.8 & 12.13 \\
\hline Soluble non starch polysaccharide (g/kg DM) & 8.4 & 23.6 & 38.0 & 5.95 \\
\hline Gross energy (MJ/kg DM) & 18.1 & 18.4 & 18.7 & 0.12 \\
\hline Amylose (g/kg DM) & 115.0 & 159.2 & 182.3 & 11.77 \\
\hline Lysine (g/kg DM) & 1.8 & 3.5 & 5.6 & 0.61 \\
\hline Threonine (g/kg DM) & 1.2 & 3.4 & 4.9 & 0.80 \\
\hline Hardness $(\%)$ & 8.4 & 31.4 & 55.5 & 11.80 \\
\hline Rate of starch digestion constant & 1.3 & 2.5 & 4.4 & 0.60 \\
\hline Protein profile - Band 1 & 2.1 & 5.0 & 7.9 & 1.08 \\
\hline Protein profile - Band 2 & 9.1 & 14.5 & 18.8 & 2.06 \\
\hline Protein profile - Band 3 & 10.2 & 18.4 & 23.6 & 3.47 \\
\hline Protein profile - Band 4 & 24.3 & 35.4 & 48.1 & 4.43 \\
\hline Protein profile - Band 5 & 20.9 & 26.6 & 37.4 & 3.30 \\
\hline
\end{tabular}

$\mathrm{g} / \mathrm{kg} \mathrm{DM}$ ) than the "without" (137 g/kg DM) and the "with fungicide" wheat had lower NDF content (135 g/kg DM) than the "without" (162 g/kg DM). The location to give wheat with the highest mean NDF was Plough $(160 \mathrm{~g} / \mathrm{kg}$ $\mathrm{DM})$ and the lowest was Terrington (138 g/kg DM), and the seed rate to give the highest mean NDF was $40(158 \mathrm{~g} / \mathrm{kg}$ $\mathrm{DM})$ and the lowest was $160(151 \mathrm{~g} / \mathrm{kg} \mathrm{DM})$. Of all the wheat samples, the Canadian wheat had the greatest mean NDF content (153 g/kg DM) and the 1998/99 wheat the lowest (132 g/kg DM).

Total starch content ranged from $547 \mathrm{~g} / \mathrm{kg}$ DM (Acbarrie, Manitoba, plot 24, Canadian wheat) to $719 \mathrm{~g} / \mathrm{kg}$ DM (Consort 78, 1998/99). Of the NI wheat the 2004 harvest had the lowest mean starch content (603 g/kg DM) and 1998/9 the highest (673 g/kg DM). The high $\mathrm{N}$ wheat from the 2005 harvest had similar starch content $(634 \mathrm{~g} / \mathrm{kg}$ DM) than the low nitrogen wheat $(645 \mathrm{~g} / \mathrm{kg} \mathrm{DM})$. The "with N" wheat from HGCA Project 2979 had lower starch (639 g/kg DM) than the "without N" wheat (665 g/kg DM), while the "with-fungicide" wheat had greater starch content (623 g/kg DM) than the "without-fungicide" (610 g/kg DM). Wheat samples from Terrington had slightly greater mean starch content (646 g/kg DM), than Rosemaund (637 g/kg DM), High Mowthorpe (636 g/kg DM) or Plough (612 g/kg $\mathrm{DM})$. The wheat from the seed rate of 640 had the similar mean starch content $(626 \mathrm{~g} / \mathrm{kg} \mathrm{DM})$ to the seed rate of 160 (612 g/kg DM). Overall, the Canadian wheat had the lowest mean starch content (579 g/kg DM) and the 1998/99 NI wheat had the highest $(673 \mathrm{~g} / \mathrm{kg} \mathrm{DM})$.

Total non-starch polysaccharides (NSP) ranged from $81.7 \mathrm{~g} / \mathrm{kg} \mathrm{DM}$ (Consort, low N, 2005) to $138.8 \mathrm{~g} / \mathrm{kg} \mathrm{DM}$
(Rialto, Limavady, 1999). The "with N" wheat from HGCA Project 2979 had slightly higher total NSP (100.5 g/kg DM) than the "without N" wheat $(97.6 \mathrm{~g} / \mathrm{kg} \mathrm{DM})$, while the "with-fungicide" wheat had slightly lower total NSP (103.2 $\mathrm{g} / \mathrm{kg} \mathrm{DM})$ than the "without-fungicide" (111.8 $\mathrm{g} / \mathrm{kg} \mathrm{DM})$. Wheat samples from Plough had greater mean total NSP (109.1 g/kg DM), than Rosemaund (107.8 g/kg DM), High Mowthorpe (105.0 g/kg DM) or Terrington $(96.0 \mathrm{~g} / \mathrm{kg} \mathrm{DM})$. The wheat with the seed rate of 640 had the lowest mean total NSP content $(106.5 \mathrm{~g} / \mathrm{kg} \mathrm{DM})$ and the seed rate of 160 had the highest (117.6 g/kg DM). Overall, the $2005 \mathrm{NI}$ wheat had the lowest mean total NSP content $(101.3 \mathrm{~g} / \mathrm{kg}$ DM) and the 1998/99 NI wheat had the highest $(117.0 \mathrm{~g} / \mathrm{kg}$ DM).

Soluble NSP ranged from $8.4 \mathrm{~g} / \mathrm{kg}$ DM (Soissons 2003) to $38.0 \mathrm{~g} / \mathrm{kg}$ DM (Haven 60, 1998/99). Of the wheat sourced from NI, the 2003 harvest had the lowest soluble NSP content (19.6 g/kg DM) and the 1998/99 harvests the highest $(26.7 \mathrm{~g} / \mathrm{kg} \mathrm{DM})$. The high $\mathrm{N}$ wheat from the 2005 harvest had similar mean soluble NSP content $(21.5 \mathrm{~g} / \mathrm{kg}$ DM) than the low N wheat (20.7 g/kg DM) and the "with N" wheat from HGCA Project 2979 also had similar mean soluble NSP content $(23.4 \mathrm{~g} / \mathrm{kg} \mathrm{DM})$ than the "without" (20.6 g/kg DM). The "with-fungicide" wheat had lower mean soluble NSP content (20.4 g/kg DM) when compared to the wheat "without" (23.4 g/kg DM) and wheat from Rosemaund had the greatest mean soluble NSP content (23.6 $\mathrm{g} / \mathrm{kg} \mathrm{DM})$ of all the HGCA Project sites, and Terrington had the least $(21.2 \mathrm{~g} / \mathrm{kg} \mathrm{DM})$. A seed rate of 160 produced wheat with similar mean soluble NSP content $(24.8 \mathrm{~g} / \mathrm{kg} \mathrm{DM})$ to a seed rate of $40(23.3 \mathrm{~g} / \mathrm{kg} \mathrm{DM})$. 
Gross energy (GE) ranged from $18.06 \mathrm{MJ} / \mathrm{kg} \mathrm{DM}$ (Zebedee, -N, HGCA Project 2979) to $18.84 \mathrm{MJ} / \mathrm{kg} \mathrm{DM}$ (BW252, AAFCWPG, plot 55, Canadian wheat). Of the NI wheat, the 2003 and 2005 harvests had similar mean GE $(18.30 \mathrm{MJ} / \mathrm{kg}$ ) to $1998 / 99(18.40 \mathrm{MJ} / \mathrm{kg})$. The high $\mathrm{N}$ wheat from the 2005 NI harvest had slightly higher mean GE $(18.35 \mathrm{MJ} / \mathrm{kg})$ than the low $(18.26 \mathrm{MJ} / \mathrm{kg})$ and the "with $\mathrm{N}$ " wheat from HGCA Project 2979 had higher mean GE $(18.40 \mathrm{MJ} / \mathrm{kg}$ ) than the "without $\mathrm{N}$ " wheat $(18.18 \mathrm{MJ} / \mathrm{kg})$, while the "with-fungicide" wheat had lower mean GE $(18.33 \mathrm{MJ} / \mathrm{kg}$ ) than the "without-fungicide" (18.51 MJ/kg). Wheat samples from Rosemaund had greatest mean GE (18.48 MJ/kg), then Plough (18.47 MJ/kg), then High Mowthorpe $(18.33 \mathrm{MJ} / \mathrm{kg})$ and finally Terrington (18.24 $\mathrm{MJ} / \mathrm{kg}$ ). The wheat with the seed rate of 40 had the greatest mean GE content $(18.52 \mathrm{MJ} / \mathrm{kg})$ and the seed rate of 640 had the lowest $(18.43 \mathrm{MJ} / \mathrm{kg})$. Overall, the Canadian wheat had the highest mean GE $(18.66 \mathrm{MJ} / \mathrm{kg})$ and the $2005 \mathrm{NI}$ wheat had the lowest $(18.30 \mathrm{MJ} / \mathrm{kg})$.

Amylose content ranged from $115 \mathrm{~g} / \mathrm{kg}$ starch (Tanker, high $\mathrm{N}, 2005)$ to $211 \mathrm{~g} / \mathrm{kg}$ (Consort, 2004). Of the wheat sourced from NI the 2005 harvest had the lowest mean amylose content (154 g/kg starch) and the 2004 harvest the highest $(173 \mathrm{~g} / \mathrm{kg}$ starch). The low $\mathrm{N}$ wheat from the 2005 harvest had greater mean amylose content (166 g/kg starch) than the high nitrogen wheat $(142 \mathrm{~g} / \mathrm{kg}$ starch). From the wheat sourced from HGCA Project 2979, the "with N" wheat had lower mean amylose content $(158 \mathrm{~g} / \mathrm{kg}$ starch) than the "without" (168 g/kg starch) and the "withfungicide" wheat had similar amylose content (149 g/kg starch) to the "without" (148 g/kg starch). The location to give wheat with the highest mean amylose content was Terrington (168 g/kg starch) and the lowest was High Mowthorpe (152 g/kg starch), and the seed rate to give the highest mean amylose was $640(159 \mathrm{~g} / \mathrm{kg}$ starch) and the lowest was 40 (155 g/kg starch). Of all the wheat samples, the GB commercial wheat had the greatest mean amylose content (168 g/kg starch) and the $2003 \mathrm{NI}$ wheat the lowest $(152 \mathrm{~g} / \mathrm{kg}$ starch).

Hardness ranged from 8.41 (Napier, Rosemaund S/R 640) to 66.65 (Hussar, Limavady, 1998 NI wheat) using the older SKCS method. Using the more recent SKCS method hardness ranged from -2.94 (Riband, -N, Rosemaund) to 74.11 (Malacca, high N, 2005 NI wheat). Unfortunately, problems occurred with both these methods. The first method could not incorporate all the wheat samples as they were not available and also more recent and accurate methods are available. For the second method, the SKCS NIRS equation, which was developed at CCFRA, was skewed and biased in order to predict samples scanned at AFBI. However, we cannot be certain that the results obtained from the adjusted SKCS equation are correct as the $\mathrm{H}$ value (Mahalabonis distance) is not affected by skewing and biasing, only the predicted results. Therefore, the $H$ value was large (average $H$ value of 35.04). Normally, the $H$ value should be less than three, indicating that the samples are similar to those in the sample database.

Using the in vitro rate of starch digestion results, starch was classified as described in the method section of the report. The rate constant was greatest for Buster 67, 1998/99 wheat (4.352\% degradation/h) and lowest for Teal, PSC, plot 46 Canadian wheat (1.326\% degradation/h).

Protein profiles were classified as described in the method section of the report. The proportion of protein in the high molecular weight (HMW) -glutenin subunits band (Band 1) ranged from 2.1 (Haven 60, 1998/9 NI wheat) to $7.9 \%$ (Soissons, 2003), the proportion in the larger low molecular weight (LMW) -glutenin and $\omega$-gliadin subunits (Band 2) ranged from 9.1 (Haven 60, 1998/9 NI wheat) to $18.8 \%$ (Robigus, +F, High Mowthorpe, HGCA Project 2979 wheat), the proportion in the smaller LMW-glutenin and $\omega$-gliadin subunits (Band 3) ranged from 10.2 (Aardvark, Downpatrick, 1998/9 NI wheat) to $23.6 \%$ (Arklow Sky, GB commercial wheat), the proportion in the $\alpha$-, $\beta$-, $\gamma$-gliadin subunits (Band 4) ranged from 24.3 (Spark -N, Terrington, HGCA Project 2979 wheat) to $48.1 \%$ (Rialto, Downpatrick, $1998 / 9$ NI wheat) and the proportion of protein in the albumins and globulins band (Band 5) ranged from 20.9 (Robigus, +F, High Mowthorpe, HGCA Project 2979 wheat) to $37.4 \%$ (Haven 60, 1998/9 NI wheat).

\section{Chemical analysis of diets}

In the animal trial from Miller et al. (2001), CP ranged from 213 to $259 \mathrm{~g} / \mathrm{kg} \mathrm{DM}$, oil ranged from 48 to $61 \mathrm{~g} / \mathrm{kg}$ DM, NDF from 102 to $153 \mathrm{~g} / \mathrm{kg} \mathrm{DM}$, ash from 65 to 78 $\mathrm{g} / \mathrm{kg} \mathrm{DM}$, starch from 361 to $428 \mathrm{~g} / \mathrm{kg} \mathrm{DM}$ and GE ranged from 18.7 to $19.1 \mathrm{MJ} / \mathrm{kg}$ DM. In the first animal trial of this study, CP ranged from 239 to $261 \mathrm{~g} / \mathrm{kg} \mathrm{DM}$, oil ranged from 52 to $67 \mathrm{~g} / \mathrm{kg}$ DM, NDF from 107 to $131 \mathrm{~g} / \mathrm{kg} \mathrm{DM}$, ash from 62 to $67 \mathrm{~g} / \mathrm{kg} \mathrm{DM}$, starch from 378 to $405 \mathrm{~g} / \mathrm{kg} \mathrm{DM}$ and GE ranged from 18.9 to $19.1 \mathrm{MJ} / \mathrm{kg} \mathrm{DM}$. In the second animal trial, CP ranged from 201 to $240 \mathrm{~g} / \mathrm{kg} \mathrm{DM}$, oil ranged from 62 to $72 \mathrm{~g} / \mathrm{kg}$ DM, NDF from 106 to $129 \mathrm{~g} / \mathrm{kg}$ $\mathrm{DM}$, ash from 61 to $68 \mathrm{~g} / \mathrm{kg} \mathrm{DM}$, starch from 398 to 457 $\mathrm{g} / \mathrm{kg} \mathrm{DM}$ and GE ranged from 18.6 to $19.0 \mathrm{MJ} / \mathrm{kg} \mathrm{DM}$. In the third animal trial, CP ranged from 183 to $218 \mathrm{~g} / \mathrm{kg} \mathrm{DM}$, oil ranged from 45 to $57 \mathrm{~g} / \mathrm{kg}$ DM, NDF from 93 to 112 $\mathrm{g} / \mathrm{kg} \mathrm{DM}$, ash from 57 to $65 \mathrm{~g} / \mathrm{kg} \mathrm{DM}$, starch from 426 to $466 \mathrm{~g} / \mathrm{kg} \mathrm{DM}$ and GE ranged from 18.8 to $19.0 \mathrm{MJ} / \mathrm{kg} \mathrm{DM}$.

\section{Animal trials}

It was found that there were very highly significant $(p<0.001)$ differences between diet treatments for all the measured parameters (total DMI, LWG and gain:feed, in vivo viscosity, ME:GE, AME content, ME:Gain, DM retention, ileal dry matter, starch and protein digestibility). 
Total DMI ranged from 61.6 (Ambrosia, -F, HM) to 85.7 g/d (Buster 71, 1998/99), with fertilizer and fungicide application and seed rate having no significant effect ( $>0.05$ ) (Table 3). Total LWG ranged from 41.9 (Ambrosia, -F, HM) to $64.2 \mathrm{~g} / \mathrm{d}$ (Buster 71, 1998/99), with wheat treated with fungicide being significantly $(\mathrm{p}<0.05)$ greater (10\%) than that without. Total gain:feed ranged from 0.67 (Predator, -N, Terr) to 0.82 (Riband, 2004), with significant differences between high and low $\mathrm{N}$ levels and seed rate ( $\mathrm{p}<0.05$ and 0.01 respectively). In vivo viscosity ranged from 3.3 (Riband, 2003) to 13.0 (Malacca, high N, 2005), with high $\mathrm{N}$ wheat having increased mean viscosity over low (8.6 cps compared with 6.9 cps, p<0.001). Both ME:GE (0.67 (Buster 67, 1998/99) to 0.78 (Predator, -N, HM)) and AME content (12.67 (Buster 67, 1998/9) to 14.71 $\mathrm{MJ} / \mathrm{kg}$ (Malacca, high N, 2005)) were significantly $(\mathrm{p}<0.05)$ affected by high and low $\mathrm{N}$ treatments. ME:gain ranged from 16.75 (Soissons, high N, 2005) to $20.65 \mathrm{MJ} / \mathrm{kg}$ (Zebedee -N, Terr), with fertilizer and fungicide application and seed rate having no significant effect. DM retention ranged from 0.697 (Napier, S/R 640, Rose) to 0.753 (Napier, high $\mathrm{N}, 2005)$, with $-\mathrm{N}$ diets giving significantly $(\mathrm{p}<0.05)$ higher (0.730) values than $+\mathrm{N}(0.719)$. Neither ileal dry matter (0.627 (Claire, high N, 2005) to 0.756 (Consort, 2003)) nor starch digestibility (0.832 (Aardvark, 2004) to 0.972 (Goodwood, low N, 2005)) were significantly ( $>0.05$ ) affected by fertilizer and fungicide application and seed rate (Table 4). However, ileal protein digestibility, which ranged from 0.703 (Consort, high $\mathrm{N}, 2005$ ) to 0.832 (Savannah, 2004), was significantly $(\mathrm{p}<0.05)$ affected by seed rate.

\section{DISCUSSION}

The wheat samples used in this study were sourced over different locations, years and growing conditions to create a wheat sample database with wide ranging chemical and physical parameters. This aim was successful in that the ranges for each of the measured parameters were greater than most quoted in literature, but still within typical limits expected for wheat (Garnsworthy et al., 2000; McCracken and Quintin, 2000; McCracken et al., 2001; Rose et al., 2001; Steenfeldt, 2001; Carré et al., 2002; Pirgozliev et al., 2003; Wilkinson et al., 2003; Rafuse et al., 2005; Samli et al., 2006).

The reported values of bird responses in this study had similar ranges to those reported in previous studies. The ranges of bird DMI, LWG and gain:feed were similar (61.6 to $85.7 \mathrm{~g} / \mathrm{d}, 41.9$ to $65.0 \mathrm{~g} / \mathrm{d}$ and 0.67 to 0.82 respectively) to those reported in similar studies by McCracken and Quintin (2000) (63.2 to $73.9 \mathrm{~g} / \mathrm{d}, 44.1$ to $51.8 \mathrm{~g} / \mathrm{d}$ and 0.67 to 0.76 , respectively) and McCracken et al. (2001) (53.5 to $77.5 \mathrm{~g} / \mathrm{d}, 41.3$ to $55.9 \mathrm{~g} / \mathrm{d}$ and 0.70 to 0.78 , respectively). In the present study, these bird performance parameters (DMI, LWG and gain:feed) were all significantly $(\mathrm{p}<0.001)$ affected by wheat sample. This agrees with findings from

Table 3. Range and standard deviation in broiler performance and nutrient utilisation

\begin{tabular}{|c|c|c|c|c|}
\hline & Minimum & Mean & Maximum & Standard deviation \\
\hline \multicolumn{5}{|l|}{ Dry matter intake $(\mathrm{g} / \mathrm{d})$} \\
\hline $7-14 \mathrm{~d}$ & 28.8 & 34.4 & 39.3 & 2.40 \\
\hline $14-21 \mathrm{~d}$ & 58.6 & 71.5 & 83.1 & 4.73 \\
\hline $21-28 d$ & 92.2 & 115.2 & 134.9 & 8.84 \\
\hline Total & 61.6 & 73.8 & 85.7 & 4.94 \\
\hline \multicolumn{5}{|l|}{ Live weight gain $(\mathrm{g} / \mathrm{d})$} \\
\hline $7-14 \mathrm{~d}$ & 21.4 & 28.5 & 33.2 & 3.34 \\
\hline $14-21 \mathrm{~d}$ & 42.4 & 57.5 & 65.1 & 5.90 \\
\hline $21-28 d$ & 58.1 & 81.8 & 96.3 & 8.45 \\
\hline Total & 41.9 & 55.9 & 64.2 & 5.67 \\
\hline \multicolumn{5}{|l|}{ Gain:feed } \\
\hline $7-14 \mathrm{~d}$ & 0.731 & 0.828 & 0.906 & 0.051 \\
\hline $14-21 \mathrm{~d}$ & 0.719 & 0.804 & 0.884 & 0.044 \\
\hline $21-28 d$ & 0.615 & 0.711 & 0.782 & 0.032 \\
\hline Total & 0.672 & 0.758 & 0.817 & 0.036 \\
\hline In vivo viscosity (cp) & 3.3 & 5.9 & 13.0 & 1.97 \\
\hline Apparent metabolizable energy (MJ/kg DM) & 12.7 & 13.9 & 14.7 & 0.44 \\
\hline ME:gain & 16.5 & 18.3 & 20.7 & 0.89 \\
\hline Dry matter retention & 0.697 & 0.721 & 0.753 & 0.013 \\
\hline Ileal dry matter digestibility & 0.627 & 0.700 & 0.756 & 0.027 \\
\hline Ileal starch digestibility & 0.832 & 0.917 & 0.972 & 0.033 \\
\hline Ileal crude protein digestibility & 0.703 & 0.769 & 0.832 & 0.033 \\
\hline
\end{tabular}


Table 4. The effect of $\mathrm{N}$ fertiliser and fungicide application and seed rate over all experiments

\begin{tabular}{|c|c|c|c|c|c|c|c|c|c|c|c|c|c|}
\hline & High N & Low $\mathrm{N}$ & $\mathrm{p}$ & $+\mathrm{N}$ & $-\mathrm{N}$ & $\mathrm{P}$ & $+\mathrm{F}$ & $-\mathrm{F}$ & $\mathrm{p}$ & S/R 640 & S/R 40 & $\mathrm{p}$ & LSD \\
\hline \multicolumn{14}{|l|}{ Dry matter intake $(\mathrm{g} / \mathrm{d})$} \\
\hline $7-14 d$ & 33.1 & 34.4 & NS & 32.5 & 33.5 & NS & 31.3 & 31.1 & NS & 33.7 & 31.4 & NS & 5.93 \\
\hline $14-21 \mathrm{~d}$ & 72.1 & 71.3 & NS & 68.5 & 66.1 & NS & 67.0 & 61.2 & NS & 68.9 & 70.2 & NS & 10.46 \\
\hline $21-28 \mathrm{~d}$ & 113.5 & 110.2 & NS & 109.2 & 104.2 & NS & 105.0 & 96.3 & $<0.05$ & 123.6 & 110.7 & NS & 13.47 \\
\hline $7-28 \mathrm{~d}$ & 72.9 & 72.0 & NS & 70.1 & 67.7 & NS & 67.8 & 63.3 & NS & 70.8 & 65.5 & NS & 7.96 \\
\hline \multicolumn{14}{|l|}{ Liveweight gain (g/d) } \\
\hline $7-14 \mathrm{~d}$ & 27.1 & 27.5 & NS & 25.4 & 24.9 & NS & 24.2 & 22.6 & NS & 25.5 & 26.8 & NS & 4.38 \\
\hline $14-21 \mathrm{~d}$ & 56.8 & 55.2 & NS & 52.7 & 49.5 & NS & 51.1 & 44.5 & $<0.01$ & 51.5 & 54.7 & NS & 7.43 \\
\hline $21-28 \mathrm{~d}$ & 81.3 & 76.8 & $<0.05$ & 76.6 & 69.4 & $<0.05$ & 73.1 & 67.2 & NS & 78.0 & 78.2 & NS & 10.78 \\
\hline $7-28 \mathrm{~d}$ & 55.1 & 53.2 & NS & 51.6 & 47.9 & NS & 49.4 & 44.8 & $<0.05$ & 51.7 & 53.2 & NS & 6.24 \\
\hline \multicolumn{14}{|l|}{ Gain:feed } \\
\hline $7-14 d$ & 0.815 & 0.800 & NS & 0.780 & 0.763 & NS & 0.772 & 0.747 & NS & 0.758 & 0.856 & $<0.05$ & 0.0654 \\
\hline $14-21 \mathrm{~d}$ & 0.790 & 0.776 & NS & 0.775 & 0.749 & NS & 0.766 & 0.731 & $<0.05$ & 0.750 & 0.784 & NS & 0.0533 \\
\hline $21-28 d$ & 0.720 & 0.693 & NS & 0.701 & 0.669 & NS & 0.699 & 0.613 & NS & 0.632 & 0.715 & $<0.05$ & 0.0811 \\
\hline $7-28 \mathrm{~d}$ & 0.756 & 0.736 & $<0.05$ & 0.735 & 0.707 & NS & 0.729 & 0.709 & NS & 0.685 & 0.755 & $<0.01$ & 0.0443 \\
\hline ME:GE & 0.763 & 0.754 & NS & 0.748 & 0.756 & $<0.05$ & 0.748 & 0.743 & NS & 0.721 & 0.726 & NS & 0.0270 \\
\hline $\begin{array}{r}\text { AME content } \\
(\mathrm{MJ} / \mathrm{kg} \mathrm{DM})\end{array}$ & 14.38 & 14.24 & NS & 14.08 & 14.24 & $<0.05$ & 14.02 & 14.04 & NS & 13.40 & 13.58 & NS & 0.507 \\
\hline ME:gain (MJ/kg) & 18.86 & 18.91 & NS & 19.18 & 19.70 & NS & 19.22 & 19.74 & NS & 17.16 & 17.98 & NS & 1.670 \\
\hline In vivo viscosity (cp) & 8.57 & 6.92 & $<0.001$ & 5.36 & 5.42 & NS & 5.57 & 6.45 & NS & 10.68 & 8.58 & NS & 2.447 \\
\hline DM retention & 0.733 & 0.725 & NS & 0.719 & 0.730 & $<0.05$ & 0.718 & 0.713 & NS & 0.697 & 0.699 & NS & 0.0322 \\
\hline NDF digestibility & 0.365 & 0.366 & NS & 0.350 & 0.326 & NS & 0.354 & 0.332 & NS & 0.346 & 0.338 & NS & 0.0341 \\
\hline Oil digestibility & 0.829 & 0.827 & NS & 0.748 & 0.754 & NS & 0.836 & 0.828 & NS & 0.804 & 0.807 & NS & 0.0256 \\
\hline Ileal DM digestibility & 0.675 & 0.685 & NS & 0.704 & 0.713 & NS & 0.711 & 0.690 & NS & 0.665 & 0.698 & NS & 0.0521 \\
\hline Ileal starch digestibility & 0.911 & 0.923 & NS & 0.926 & 0.952 & NS & 0.948 & 0.921 & NS & 0.900 & 0.927 & NS & 0.0587 \\
\hline Ileal $\mathrm{CP}$ digestibility & 0.755 & 0.742 & NS & 0.764 & 0.747 & NS & 0.769 & 0.770 & NS & 0.729 & 0.782 & $<0.05$ & 0.0563 \\
\hline
\end{tabular}

ME:GE = Metabolizable energy:gross energy, AME = Apparent metabolizable energy, DM $=$ Dry matter, NDF $=$ Neutral detergent fibre, $\mathrm{CP}=\mathrm{Crude}$ protein, $\mathrm{N}=$ Nitrogen, $\mathrm{F}=$ Fungicide, $\mathrm{S} / \mathrm{R}=$ Seed rate, $\mathrm{P}=$ Probability, $\mathrm{LSD}=$ Least significant difference.

some studies (Rose et al., 1993; Waldron et al., 1995; Collier et al., 1996; Steenfeldt, 2001), but not others (McCracken et al., 2001; Pirgozliev et al., 2003). The ranges of ME:GE (0.67 to 0.78) and AME (12.67 to 14.79 $\mathrm{MJ} / \mathrm{kg}$ ) content from this study compare well with findings from literature (McCracken and Quintin, 2000; McCracken et al., 2001). However, the significant differences $(\mathrm{p}<0.001)$ in ME:GE between wheat samples observed in this study and other studies (Steenfeldt, 2001; Pirgozliev et al., 2003) were not observed in McCracken and Quintin (2000) and McCracken et al. (2001). These disagreements may be attributed to the wide range of wheat samples being compared, the number of samples being compared and the experimental time periods employed. The differences may also be due to variety as it has been reported that wheat variety significantly affects in vivo viscosity (McCracken and Quintin, 2000; McCracken et al., 2001; Steenfeldt, 2001; Pirgozliev et al., 2003). Although no varietal effects were apparent in the current study.

Environmental factors during wheat growth appeared to have an effect on bird performance. The high level of $\mathrm{N}$ fertilizer application tended to benefit bird performance, with increases over the low level application of 1.2, 3.4, 2.6 and $2.2 \%$ in DMI, LWG, gain:feed and AME content respectively. This trend was observed again when comparing the $+\mathrm{N}$ and $-\mathrm{N}$ samples. Increases of 3.4, 7.2 and $3.8 \%$ in DMI, LWG and gain:feed respectively were observed with $\mathrm{N}$ application, although these differences were not always statistically significant.

In literature, the effects of the environment have been better described for barley than for wheat. Scott et al. (1998) reported that the growing environment had a significant effect on AME for wheat and barley (without enzyme) and bird performance parameters for barley only. They reported that fertilizer affects the level of $\beta$-glucans and the nutritive value of barley and that its suitability as a feedstuff for growing broilers are more or less affected by varying $\beta$ glucan concentration. Fungicide application also seemed to have a positive effect on bird performance, with $+\mathrm{F}$ treated wheat increasing bird DMI, LWG and gain:feed by $6.6,9.3$ and $2.7 \%$, over the $-\mathrm{F}$ wheats. A significant increase of 9.3\% in gain:feed was also observed at the low seed rate of 40 compared to $640 \mathrm{seeds} / \mathrm{m}^{2}$. Therefore, changes in the environmental conditions, that is, fertilizer and fungicide application and seed rate, can affect the feeding value of wheat.

Since these considerable differences in performance variables have been observed between the wheat samples it 
was hopeful that some meaningful correlations with the measured wheat chemical and physical properties could be established. An understanding of the causes of differences in nutritional value between wheat samples would give wheat breeders information for cultivar development and feed wheat buyers the knowledge of which wheat parameters are indicative of nutritive value.

\section{ACKNOWLEDGEMENTS}

The authors gratefully acknowledge the cooperation of Dr Ethel White (Plant Testing Station, AFBI), Professor Roger Sylvester-Bradley (ADAS), Mr John Sloss (Moy Park) and Dr Tom Scott (Agri-Food Research Centre) in obtaining the wheat samples. Dr David Kilpatrick and Mrs Sally Dawson (Biometrics Division, AFBI) who provided advice and help with the statistical analysis. The work was funded by the Department of Agriculture and Rural Development (Northern Ireland) and the Home Grown Cereals Authority.

\section{REFERENCES}

Ball, M. E. E., B. Owens and K. J. McCracken. 2013. Chemical and physical predictors of the nutritive value of wheat in broiler diets. Asian-Aust. J. Anim. Sci. 26:97-107.

Carré, B., A. Ida, S. Maisonnier, J. P. Melcion, F. X. Oury, J. Gomez and P. Pluchard. 2002. Relationships between digestibilities of food components and characteristics of wheats (Triticum aestivum) introduced as the only cereal source in a broiler chicken diet. Br. Poult. Sci. 43:404-415.

Choct, M. and G. Annison. 1990. Anti-nutritive effect of wheat pentosans in broiler diets. Br. Poult. Sci. 31:811-821.

Choct, M. and G. Annison. 1992. Anti-nutritive effect of wheat pentosans in broiler chickens: Role of viscosity and gut microflora. Br. Poult. Sci. 33:821-834.

Collier, J., P. Rose, P. Kettlewell and M. Bedford. 1996. Wheat varieties and the energy retention of broiler chickens. Br. Poult. Sci. 37:S50-51.

Garnsworthy, P. C., J. Wiseman and K. Fegeros. 2000. Prediction of chemical, nutritive and agronomic characteristics of wheat by near infrared spectroscopy. J. Agric. Sci. (Cambridge) 135: 409-417.

George, J. and K. J. McCracken. 2003. Effect of year and location of growth and yearxlocation interactions on the physical and chemical characteristics of wheat grown in Northern Ireland. Proc. $14^{\text {th }}$ Eur. Symp. Poult. Nutr., Lillehammer, Norway.

Gutierrez-Alamo, A., P. Perez De Ayala, M. W. A. Verstegen, L. A. Den Hartog and M. J. Villamide. 2008. Variability in wheat : factors affecting its nutritional value. World Poult. Sci. J. 64: 20-39.
McCracken, K. J. and G. Quintin. 2000. Metabolizable energy content of diets and broiler performance as affected by wheat specific weight and enzyme supplementation. Br. Poult. Sci. 41:332-342.

McCracken, K. J., M. R. Bedford and R. A. Stewart. 2001. Effects of variety, the $1 \mathrm{~B} / 1 \mathrm{R}$ translocation and xylanase supplementation on nutritive value of wheat for broilers. Br. Poult. Sci. 42:638-642.

McCracken, K. J., C. M. Preston and C. Butler. 2002. Effects of wheat variety and specific weight on dietary apparent metabolizable energy concentration and performance of broiler chicks. Br. Poult. Sci. 43:253-260.

Metayer, J. P., F. Grosjean and J. Castaing. 1993. Study of variability in French cereals. Anim. Feed Sci. Technol. 43:87108.

Miller, H. M., J. M. Wilkinson, K. J. McCracken, A. Knox, J. $\mathrm{McNab}$ and S. P. Rose. 2001. Nutritional value to farm livestock of wheat of low specific weight. HGCA Project Report No. 260, HGCA, London.

Pirgozliev, V. R., C. L. Birch, S. P. Rose, P. S. Kettlewell and M. R. Bedford. 2003. Chemical composition and the nutritive quality of different wheat cultivars for broiler chickens. Br. Poult. Sci. 44:464-475.

Rafuse, J. L., F. G. Silversides, M. R. Bedford and P. H. Simmins. 2005. Effect of cultivar and enzyme supplementation on nutrient availability and performance of broilers fed Maritime Canadian wheat. Can. J. Anim. Sci. 85:493-499.

Rose, S. P., P. S. Kettlewell, M. S. Reynolds and M. R. Watts. 1993. The nutritive value of different wheat varieties for poultry. Proc. Nutr. Soc. 52:206A.

Rose, S. P., L. A. Tucker, P. S. Kettlewell and J. D. A. Collier. 2001. Rapid tests of wheat nutritive value for growing chickens. J. Cereal Sci. 34:181-190.

Samli, H. E., N. Senkoylu, M. L. Ozduven and A. Agma. 2006. An in vitro assessment of nutritional and physical characteristics of wheat varieties obtained from Thrace and Aegean regions for poultry. Pak. J. Nutr. 5:83-85.

Scott, T. A., F. G. Silversides, H. L. Classen, M. L. Swift and M. R. Bedford. 1998. Effect of cultivar and environment on the feeding value of Western Canadian wheat and barley samples with and without enzyme supplementation. Can. J. Anim. Sci. 78:649-656.

Steenfeldt, S. 2001. The dietary effect of different wheat cultivars for broiler chickens. Br. Poult. Sci. 42:595-609.

Uhlen, A-K., S. Sahlstrom, E. M. Magnus, E. M. Faergestad, J. A. Dieseth and K. Ringlund. 2004. Influence of genotype and protein content on the baking quality of hearth bread. J. Sci. Food Agric. 84:887-894.

Waldron, L. A., S. P. Rose and P. S. Kettlewell. 1995. Rate of in vitro starch digestion of 2 wheat varieties and its relationship to broiler chicken productive performance. Br. Poult. Sci. 36: 875-876.

Wilkinson, J. M., H. M. Miller, K. J. McCracken, A. Knox, J. McNab and S. P. Rose. 2003. Effect of specific weight on the metabolizable energy content of four cultivars of wheat grain in ewes. Anim. Feed Sci. Technol. 105:215-224. 